\author{
Gaurav Rattan and Maninder Kumar
}

\title{
CARBON MONOXIDE OXIDATION USING COBALT CATALYSTS: A SHORT REVIEW
}

\author{
Dr. S. S Bhatnagar University, Institute of Chemical Engineering \& Technology, \\ Panjab University, 160014 Chandigarh, India; grattan@pu.ac.in
}

Received: October 21, 2013 / Revised: N ovember 25, 2013 / Accepted: February 02, 2014

(C) Rattan G., Kumar M., 2014

\begin{abstract}
The preparation methods and main characteristics of known catalysts for carbon monoxide oxidation have been examined. A short review in a tabular form which facilitates a quick view on catalysts for $\mathrm{CO}$ oxidation (mainly cobalt ones) is represented.
\end{abstract}

Keywords: cobalt, catalyst, carbon monoxide, oxidation, catalytic convertor, automobile exhausts.

\section{Introduction}

Carbon monoxide is an odourless, colourless and toxic gas. It is about $3 \%$ lighter than air, therefore it is impossible to see, taste or smell the toxic fumes. It is also called as a silent killer. It is a non-irritant gas and is slightly soluble in water. It is generally produced and released from the partial combustion process of fossil fuel. For instance, during the cold start period of vehicles, a lot of carbon monoxide $(\mathrm{CO})$ is released in atmosphere [1]. It is also a common industrial hazard created due to incomplete combustion of any carbon based fuel, such as coal, petrol, diesel, liquefied petroleum gas (LPG), natural gas, charcoal and wood [2]. Umpteen numbers of other sources are there which add carbon monoxide to the atmosphere such as gas appliances (ovens, stoves, dryers), liquid propane fuelled equipment, tobacco smoke, house fires, blocked chimneys, charcoal grills, etc. Carbon monoxide is responsible for a large percentage of the accidental poisonings and deaths reported throughout the world each year [3]. Certain conditions exist in both the indoor and outdoor environments that cause a small percentage of the population to become exposed to dangerous levels of carbon monoxide. High levels of $\mathrm{CO}$ can be fatal causing death within minute, i.e. carbon monoxide reacts or binds with the haemoglobin (which is responsible for oxygen carrying) to form carboxyhaemoglobin which greatly reduces oxygen carrying capacity, because $\mathrm{CO}$ has more affinity to react with haemoglobin than $\mathrm{O}_{2}$. Hence if there is a lot of $\mathrm{CO}$ in the air, the body may replace oxygen in blood with $\mathrm{CO}$. This blocks oxygen from getting into the body, which can damage tissues and result in death [4].

The efforts made in the last century for the abetment of pollution from the mobile sources are still in progress. The catalytic oxidation of $\mathrm{CO}$ to $\mathrm{CO}_{2}$ is a reaction that has been studied especially by automotive industry [5-6]. Numbers of parameters are responsible for pollution created by mobile sources. The effectiveness of catalytic converters depends on the exhaust gas temperature, which is fairly low during cold-start [7-10]. Therefore the emissions of pollutants are very high during the cold start [11]. Cold start emission depends on numbers of factors [5] such as misfiring, incomplete flame propagation, wall wetting, rich fuel/air charge, crevice storage of the fuel/air charge and its release, oil dilution with liquid and fuel vapour, wall quenching, poor postflame oxidation, exhaust valve leakage, inlet valve leakage and lubricating oil. In order to tackle the problem of cold start various studies have been done [2, 12-13] Along with $\mathrm{CO}$, VOCs are another form of pollutants that comes out during cold start [11]. Climate change is a serious environmental challenge and stringent regulations have been adopted by the Government from time to time to tackle it [4]. They have set mandatory reduction targets for all major industries that produce greenhouse gases, like carbon dioxide, that cause climate change. The challenges for the researchers are to make or develop such methods which can be used for the generation of the clean energy which is required by the growing industries. The methods that are used till date in many industries lead to air pollution which adds harmful products like $\mathrm{NO}_{\mathrm{x}}$, smog, smoke, VOCs, $\mathrm{CO}, \mathrm{HC}, \mathrm{CO}_{2}$, etc. to atmosphere. Various catalysts have been developed for VOCs [14-16] and $\mathrm{NO}_{\mathrm{x}}[17-18]$ removal. Sources used in industries for 
energy generation should be substituted for the eco friendly fuels. Coal is used for generation of energy at power plants. Coal contains sulphur which results in $\mathrm{SO}_{\mathrm{x}}$ which in turn is responsible for the acid rain, smog formation, etc. Various equipments are available for the removal of particulate matters, conversion of harmful gases into less harmful ones, but the treatment of these pollutants is so expensive that the products would not be feasible in economic terms under those conditions. So, we have to develop the techniques which are less expensive compared to the present scenario. Another source of air pollution is from the household activities in rural or urban areas. In the last three decades various norms were employed and amended from time to time in order to check the air pollution, but we are still lacking them due to improper management.

\section{Catalysts for CO Oxidation}

In literature many catalysts including base metals, noble metals, nano-catalyst and mixture of base and noble metals have been reported for $\mathrm{CO}$ oxidation.

A good catalyst should have high activity, selectivity, thermal characteristics, stability, mechanical strength and low cost [19]. For the present study the types of catalyst used for $\mathrm{CO}$ oxidation can be divided as follows:

1. Noble metals catalysts

2. Base metals catalysts

3. Perovskites

\subsection{Base M etal Catalysts}

Base metal catalysts have been considered as an alternative for $\mathrm{CO}$ oxidation because they also exhibit the same characteristics as those of the noble metal catalysts at elevated temperatures. They are deposited on the support which is generally a cheap compound having a very high surface area per unit gram of the catalyst. Transition metals are usually used as a precursor. They are embedded on the support which makes the reaction feasible for a particular reaction. Various transition metals such as copper, cobalt, ceria, zirconium, manganese, iron, etc. are used for the catalyst preparation. Researchers all around the world have tested and explored these base metals for CO oxidation. In $1920 \mathrm{~W}$. Bray [20] for the first time reported a catalyst hopcalite [21-23] which can oxidise $\mathrm{CO}$ and later on it was tested for many reactions that include oxidation. Hopcalite is basically a mixture of base metals $\left(50 \% \mathrm{MnO}_{2}, 30 \% \mathrm{CuO}, 15 \% \mathrm{Co}_{2} \mathrm{O}_{3}\right.$ and $\left.5 \% \mathrm{Ag}_{2} \mathrm{O}\right)$ and has many applications in day to day life as well. After the discovery of hopcalite just of the need for $\mathrm{CO}$ conversion to $\mathrm{CO}_{2}$ in the air, it was found that the activity of gold based catalyst was increased with the addition of small amount of base metals (copper) [24]. With time, a lot of advancements have been done by the researchers by substituting different base metals for the hopcalite which enhances its catalytic activity by varying the composition, different methods of preparation, addition of promoters and stabilizers. Effects of alumina support on cobalt catalyst were studied [25] by varying the synthesis methods revealed that the catalyst prepared by the impregnation methods has a high activity. The oxidation of $\mathrm{CO}$ over $\mathrm{Co}_{3} \mathrm{O}_{4} / \gamma-\mathrm{Al}_{2} \mathrm{O}_{3}$ at room temperature studied by [26] reported that the pre-oxidised catalyst shows the higher activity for $\mathrm{CO}$. The comparative study of $\mathrm{CO}$ oxidation by using three different metals was also done by $\mathrm{H}$. Matralis et al. [27]. Three different catalysts were $\mathrm{Pt} / \gamma-\mathrm{Al}_{2} \mathrm{O}_{3}, \mathrm{Au} / \alpha-\mathrm{Fe}_{2} \mathrm{O}_{3}$ and $\mathrm{CuO}-\mathrm{CeO}_{2}$. It was shown that at relatively low reaction temperatures $\mathrm{Au} / \alpha-$ $\mathrm{Fe}_{2} \mathrm{O}_{3}$ catalyst is superior to other two ones for the selective $\mathrm{CO}$ oxidation.

\subsection{N oble M etal Catalysts}

Automotive industry utilizes large amounts of precious metal catalysts because of their high activity and selectivity and stability under various reaction conditions. They do not form oxides under normal conditions, i.e. the oxides of noble metals are not stable. Noble metals were used for the first time for the oxidation of CO by Cohn et al. [23] and the advancement of these processes is still going on in order to undergo $100 \%$ completion of $\mathrm{CO}$ at low temperature. These catalysts are used because of their ability to disperse nano-scale precious metal particles on supports with high surface area such as carbon, silica, and alumina. Noble metals such as platinum, palladium, gold and rhodium with various supports are used in a catalytic convertor (described below) for the oxidation of $\mathrm{CO}$ and have been studied by umpteen number of researchers in order to improve their activity and to make them economical. The supports used are alumina, magnesium, silica, etc. [24, 29, 30]. In 1965 G. Cohn [28] proposed $\mathrm{Pt} / \mathrm{Al}_{2} \mathrm{O}_{3}$ as a catalyst for the oxidation of carbon monoxide which later on was studied and reported by many researchers. U. Olsbye et al. [31] prepared the catalyst of platinum supported on alumina by various methods. The kinetics of $\mathrm{CO}$ oxidation on platinum was studied [32], a reaction mechanism for the oxidation and $\mathrm{CO}$ reduction on the platinum surface was described [33] and ultra fine gold particles which were very active for $\mathrm{H}_{2}$ and $\mathrm{CO}$ were prepared [34]. The particles were supported by different supports of base metals which were active even at the temperature as low as $203 \mathrm{~K}$. H. Igarashi et al. [35] reported the oxidation of $\mathrm{CO}$ over platinum catalyst supported on zeolite. M. Ozawa et al. [36] studied CO oxidation over $\mathrm{Pt} / \mathrm{Ce}-\mathrm{Zr}$ oxide catalysts with a low content of platinum 
and cerium components and the results showed that highly dispersed platinum particles and the oxygen storage capacity of ceria and zirconium contributed to the high catalytic activities of $\mathrm{CO}$ oxidation.

\subsection{Perovskites}

In 1970 D. Meadowcroft [37] for the first time described the use of perovskites in zinc air batteries. One of the greatest advantages of perovskites is that they have high oxygen coverage on the surface depending on binding energy for oxygen. They can release and take up oxygen in a reversible way [38]. Various mechanisms were also described for oxygen mobility on these surfaces [39]. The general formula of these oxides is $\mathrm{ABO}_{3}$ in which the cation A ( $\mathrm{La}, \mathrm{Ce}, \mathrm{Pr}, \mathrm{Cs}, \mathrm{Sr}, \mathrm{Ba}, \mathrm{Ca})$ of a larger size is responsible for the thermal resistance of the catalyst, whereas the cation $\mathrm{B}(\mathrm{Co}, \mathrm{Fe}, \mathrm{Cu}, \mathrm{Ni}, \mathrm{Mn}, \mathrm{Cr})$ of smaller size accounts for the catalytic performance. Various methods in literature are available for synthesis of these catalysts [40]. Among the possible compositions, cobalt and manganese based perovskites are highly active [41-42]. Therefore extensive amount of work has been done on pervoskites catalysts containing cobalt which helps in CO oxidation [43].

\subsection{Three-W ay Catalytic Convertor}

Catalysts that are used for catalytic combustion are mainly noble metals, very active at low temperature, as they play the major role in the three way catalytic converter. The three noble metals that are used there are: platinum, palladium and rhodium [44]. Due to a partial combustion, gases entering inside the catalytic converter consist of a mixture of $\mathrm{CO}$, unburned hydrocarbons (HC) and oxides of nitrogen $\left(\mathrm{NO}_{\mathrm{x}}\right)$, which are harmful for environment. The catalytic converter consists of two ceramic blocks with microducts which are used in order to increase the contact zone between gasses and the catalyst. The increase in surface area is greater than the area of football field. The ducts consist of platinum and rhodium in one block while platinum and palladium in the other one, acting as catalysts. As the gas enters inside, nitrogen molecules are first to react. The catalyst causes the oxides of nitrogen to reform into nitrogen and oxygen, respectively. The gas then flows through the microducts of the $2^{\text {nd }}$ ceramic block where it reacts with platinum and palladium. Inside the microducts of the $2^{\text {nd }}$ ceramic block, $\mathrm{CO}$ and unburned hydrocarbons react with oxygen molecule to form carbon dioxide and water vapours. The unburned hydrocarbons also react with oxygen to form water and carbon. And hence, exhaust gases now becomes less toxic having the mixture of $\mathrm{CO}_{2}, \mathrm{~N}_{2}$ and water vapours. However, their use is not up to the mark in terms of high price, low thermal stability and tendency to poisoning. There is decrease in the activity of the catalyst with time and the development of any catalyst requires an economic consideration according to the usage of the catalyst. The activity of the catalyst has been neglected many times keeping in view its poisoning, maintenance and regeneration problem. Various factors are responsible for deactivation of the catalyst such as: 1) deposited poisons that cover the active sites of the catalyst and partially plug the pore entrance; 2) chemisorbed poison which is the result of the compounds that are present in the reactant gasses such as sulphur which chemisorbed on the catalyst surface. The three-way catalytic convertor has the same problem of poisoning; 3) diffusion poisons that result due to blocking the pore mouths of the catalyst and prevent the reactant from diffusing into the inner surface of the catalyst.

\subsection{Preparation Methods}

If we rearrange the atoms in coal, we get diamonds. If we rearrange the atoms in sand (and add a pinch of impurities) we get computer chips. If we rearrange the atoms in dirt, water and air we get grass. Similarly catalysts are made up of atoms and its activity depends upon how those atoms are arranged. By numerous studies it has been established that the preparation method could exert a basic influence on the structural properties of the catalysts, like surface area, component dispersion and strength of interaction, which in turn determines the redox properties and reactivity of the final catalysts. Therefore methods of preparation are also developing at a faster rate as that of the development of new catalysts. There are various methods for preparation of the catalyst [45]:

1. Wet impregnation method.

2. Co-impregnation method.

3. Precipitation deposition method.

4. Co-precipitation of $\mathrm{Cu}$ and $\mathrm{Ce}$ method.

5. Urea gelation method.

6. Urea nitrate combustion method.

7. Solution combustion method.

8. Citric acid sole-gel method.

9. Surfactant assisted method.

10. Solvothermal method.

11. Leaching method.

12. Chelating method.

13. Inert gas condensation (IGC) method.

14. Electroless method.

15. Laser vaporization and controlled condensation.

16. Solvated metal atom impregnation method.

17. Combinatorial synthesis of mixed metal oxides.

18. Chemical vapour deposition.

19. Reverse micelle method.

20. Modified reverse-phase microemulsion method. 
21. Gas phase grafting method.

22. Liquid phase grafting method.

23. Co-sputtering and position.

24. Alternate method.

\subsubsection{Chemical vapour deposition (CVD) technique}

There is no inference of solvent and no need of drying by using CVD method. The advantage over the traditional impregnation method is that any hazardous waste is also eliminated if present. These methods may also offer a better control of the precursor adsorption process.

a) Atomic layer deposition. Precursor is chemisorbed on the support, this technique was previously known as the atomic layer epitaxy (ALE) [46]. The reactants to be chemisorbed must be volatile and thermally stable at reaction temperature. When the conditions of self-terminating surface reactions are fulfilled, only reactions between functional groups at the surface and the catalyst precursor occur.

b) Gas phase adsorption technique was adopted by A.Rautiainen et al. [47] and described that both $\mathrm{Co} / \mathrm{SiO}_{2}$ and $\mathrm{Co} / \mathrm{Al}_{2} \mathrm{O}_{3}$ catalysts were prepared by chemisorption of cobalt acetylacetonates, $\mathrm{Co}(\mathrm{acac})_{2}$ or $\mathrm{Co}(\mathrm{acac})_{3}$ from the gas phase onto the support. The support was kept in a fixed bed and the precursors were evaporated at 443 or $453 \mathrm{~K}$. Nitrogen was used as a carrier gas for chemisorptions of precursors on the support. The catalyst preparation by ALD consisted of the following subsequent steps: a) preheating of the support; b) chemisorption of the gaseous cobalt precursor up to surface saturation and c) removal of the remaining ligands by calcination in the synthetic air. Steps (b) and (c) were followed by a nitrogen purge. The cobalt content of the catalysts was increased by repeating steps (b) and (c).

\subsubsection{Reverse micelle method}

Reverse micelle method [48-49], as a kind of soft technique was used for obtaining the uniform and size controllable nanoparticles. The droplet dimension can be modulated by various parameters, in particular $(W=[$ water $] /[$ surfactant $])$. Several reverse micelle systems, especially AOT ternary water-in-oil system, have been used for preparing nanoparticles. Recent studies indicated that with the assistant of co-surfactant, the size of nanoparticles prepared in a quaternary reverse micelle system is more controllable. The reversed micelles containing micro droplets of aqueous $\mathrm{FeSO}$ were prepared by T. Kinoshita et al. [48] in an $n$-octane bath by mixing it with cetyltrimethylammonium bromide (CTAB) and 1-butanol as a surfactant and a co-surfactant, respectively. Firstly, FeSO in the reversed micelles was reduced by addition of aqueous sodium borohydride $\left(\mathrm{NaBH}_{4}\right)$ under agitation with an ultrasonic homogenizer to obtain a colloidal dispersion of metalliciron. Secondly, an aqueous solution of $\mathrm{HAuCl}_{4}$ was added to the solution. Then $\mathrm{Au}^{3+}$ was reduced by the same reducing agent. During the procedure, the reaction temperature was kept at $303 \mathrm{~K}$, and argon gas bubbles were produced in the micelle solution to purge the oxidizing atmosphere. The products were then dried under vacuum, and the surfactant was rinsed off to obtain a powder sample.

\subsubsection{Modified reverse-phase microemulsion method}

Firstly, two kinds of solution (solutions A and B) are prepared [50]. Solution A is composed of $15.05 \mathrm{~g}$ of NP-7, $35.05 \mathrm{~g}$ of cyclohexane, and $8.05 \mathrm{~g}$ of $n$-butyl alcohol. Solution $\mathrm{B}$ is obtained with the addition of $2.00 \mathrm{~g}$ of $\mathrm{NH}_{3} \cdot \mathrm{H}_{2} \mathrm{O}(16 \%)$ to the cobalt acetate aqueous solution $\left(0.13 \mathrm{~g}\right.$ of $\mathrm{Co}(\mathrm{OAc})_{2} \cdot 4 \mathrm{H}_{2} \mathrm{O}$ and $5.35 \mathrm{~g}$ of deionized $\left.\mathrm{H}_{2} \mathrm{O}\right)$. Microemulsion is obtained by the blending of solutions A and B. After stirring for $15 \mathrm{~min} 5.2 \mathrm{~g}$ of TEOS is added slowly to this microemulsion under stirring. After stirring for $12 \mathrm{~h}, 10 \mathrm{ml}$ of acetone is added to destroy the microemulsion. Then it is centrifugated, washed with hot ethanol three times, and dried at $353 \mathrm{~K}$ for $12 \mathrm{~h}$. This material is denoted as $\mathrm{Co}-\mathrm{SiO}_{2}$; scanning rate is $5 \% \mathrm{~min}$.

\subsubsection{Gas-phase grafting method}

Catalyst prepared by the gas phase grafting method [51] was in the reactor type equipment where the pressure can be reduced to the minimum of $0.1 \mathrm{~Pa}$. The low pressure was used for removing physically adsorbed water at the temperature of $473 \mathrm{~K}$ for $4 \mathrm{~h}$. The catalyst was further treated with oxygen at $2.7 \mathrm{kPa}$ and $473 \mathrm{~K}$ for $30 \mathrm{~min}$ to remove organic residue and to oxidize the surface. The precursor was heated to a fixed temperature of $306 \mathrm{~K}$ to gradually evaporate a measured amount. The precursor was adsorbed on the metal oxide supports that were mounted in the reaction vessel and calcined in the air at fixed temperature in the range of $473-773 \mathrm{~K}$ to decompose into metallic gold particles on the support surface.

\subsubsection{Liquid phase grafting method}

Liquid phase grafting (LG) method [52] is used for depositing gold on several metal oxide supports such as $\mathrm{TiO}_{2}, \mathrm{Al}_{2} \mathrm{O}_{3}, \mathrm{SiO}_{2}$, etc. A weighted amount of the metal oxide support was introduced into an aqueous solution of $\mathrm{HAuCl}_{4}, \mathrm{Me}_{2} \mathrm{Au}(\mathrm{acac})$ and acetone. The mixture was kept in a refrigerator overnight and finally this solvent and metal oxide were separated by filtration and the metal oxide with the gold absorbed precursor which was calcined in the air at $673 \mathrm{~K}$. 


\subsubsection{Co-sputtering and position}

Columnar-structured porous films of $\mathrm{Co}_{3} \mathrm{O}_{4}$ were prepared on glass substrates by the oblique deposition of sputtered species emitted from a disk target of $\mathrm{Co}_{3} \mathrm{O}_{4}$ in a magnetron sputtering equipment [53]. During deposition the glass substrate was kept heated at $523 \mathrm{~K}$ and was rotated at $15 \mathrm{rpm}$. The distance between the target and the substrate was about $130 \mathrm{~mm}$ and the incident angle of the sputtered species against the substrate was about $45^{\circ}$. The content of $\mathrm{Au}$ in the films depends on the area of Au plate fixed on $\mathrm{Co}_{3} \mathrm{O}_{4}$ target. As an advanced modification, simultaneous co-sputtering deposition was also conducted to prepare $\mathrm{Au} / \mathrm{Co}_{3} \mathrm{O}_{4}$ films.

\subsubsection{Alternative methods for preparation of gold nanoparticles}

Titania Degussa P25 was used as the support and solid $\mathrm{HAuCl}_{4} \cdot 3 \mathrm{H}_{2} \mathrm{O}$ - as the gold precursor [54]. Before preparation $\mathrm{TiO}_{2}$ was previously dried in the air at $373 \mathrm{~K}$ for at least $24 \mathrm{~h}$. All of the preparations were performed in the absence of light, which is known to decompose the gold precursors. $1 \mathrm{~g}$ of $\mathrm{TiO}_{2}$ was added to $100 \mathrm{ml}$ of an aqueous solution of gold precursor. The amount of gold in the solution corresponds to a maximum gold loading of $8 \mathrm{wt} \%$ on $\mathrm{TiO}_{2}$. After deposition of gold onto $\mathrm{TiO}_{2}$ it was followed by: (i) separation from the precursor solution by means of centrifugation (12 $000 \mathrm{rpm}$ for $10 \mathrm{~min}$ ); (ii) washing (the solids were suspended in water $(100 \mathrm{ml} / \mathrm{g})$, stirred for $10 \mathrm{~min}$ at RT, and centrifuged again. This washing procedure was repeated four times to remove residual $\mathrm{Cl}^{-}$and $\mathrm{Na}^{+}$ions as well as Au species not integrating the support); (iii) drying under vacuum at $373 \mathrm{~K}$ for $2 \mathrm{~h}$; (iv) calcination at $573 \mathrm{~K}$ (300 mg of sample was heated in a flow. Calcination treatment leads to the decomposition of $\mathrm{Au}(\mathrm{III})$ complexes into gold metal particles); (v) storage of the samples away from light and under vacuum in a desiccator at RT. Indeed, a strong increase in the average particle size of the calcined samples was observed when samples are stored in the air even for a short period (for instance, from 1.8 to $3 \mathrm{~nm}$ for a sample left in the air for about 10 days). After several months of storage away from light in a desiccator, the average particle size also slightly increases (for instance, from 1.7 to $2.1 \mathrm{~nm}$ after 10 months of storage). To avoid this effect, the samples were stored after drying, and calcination was performed when needed.

Table

Recent literature review on cobalt catalyst for $\mathrm{CO}$ oxidation reactions

\begin{tabular}{|c|c|c|c|c|}
\hline No. & Catalyst, prep. method & Exp. operating parameter & Remark & Ref. \\
\hline 1 & 2 & 3 & 4 & 5 \\
\hline 1 & $\begin{array}{c}\text { Co promoted Pd, } \\
\text { intermittently } \\
\text { impregnating, calc. temp. } \\
773-823 \mathrm{~K}\end{array}$ & $\begin{array}{c}\text { Horizontal quartz tube reactor, } \\
\text { XRD, SET, and TEM }\end{array}$ & $\begin{array}{l}\text { Different samples of the catalyst are } \\
\text { prepared by varying cobalt and palladium } \\
\text { content. The activity of these samples is } \\
\text { described }\end{array}$ & [44] \\
\hline 2 & $\begin{array}{l}\text { Co, Ce promoted } \mathrm{Pt} \text { and } \\
\mathrm{Pd}, \mathrm{Pt} \text { and } \mathrm{Pd} \text { applied by } \\
\text { impregnation method, } \\
\text { calc. at } 823 \mathrm{~K}\end{array}$ & $\begin{array}{l}\text { Quartz-tube flow reactor, } \\
\text { XPS, and } \mathrm{BET}, 1.0 \% \mathrm{CO} \text {, } \\
0.15 \% \mathrm{C}_{3} \mathrm{H}_{6} \text { and } 1.38 \% \mathrm{O}_{2} \text {, } \\
\text { balanced with } \mathrm{N}_{2} \text {, space } \\
\text { velocity }(\mathrm{SV}) \text { of } \\
90000 \mathrm{~h}^{-1}(\mathrm{NTP})\end{array}$ & $\begin{array}{l}8 \text { different samples were prepared by } \\
\text { varying the composition of Pt and } \mathrm{Pd} \text {, The } \\
\text { catalytic activity of Pt is promoted by Co } \\
\text { oxide in both lean and rich reactant gas, but } \\
\mathrm{CoO}_{\mathrm{x}} \text { does not promote the activity of } \mathrm{Pd}\end{array}$ & {$[55]$} \\
\hline 3 & $\begin{array}{l}\text { Pt and Co Oxide, } \\
\text { impregnation method }\end{array}$ & $\begin{array}{l}\text { Quartz flow reactor, } \\
1.0 \mathrm{~mol} \% \mathrm{CO} \text { and } 0.6 \mathrm{~mol} \% \\
\mathrm{O}_{2} \text {, at the flow rate of } \\
200 \mathrm{ml} / \mathrm{min}\end{array}$ & $\begin{array}{c}\mathrm{Pt} / \mathrm{Al}_{2} \mathrm{O}_{3}, \mathrm{CoO}_{\mathrm{x}} / \mathrm{Al}_{2} \mathrm{O}_{3}, \\
\mathrm{Pt} / \mathrm{CoO}_{\mathrm{x}} / \mathrm{Al}_{2} \mathrm{O}_{3} \text { are prepared to oxidise } \\
\mathrm{CO} \text {. This low-temperature activity of the } \\
\text { cobalt containing catalysts was found to be } \\
\text { independent of the presence of platinum }\end{array}$ & {$[56]$} \\
\hline 4 & $\begin{array}{c}\mathrm{Au} / \mathrm{MO}_{x} / \mathrm{Al}_{2} \mathrm{O}_{3} \\
\text { homogeneous deposition } \\
\text { precipitation method, calc. } \\
\text { temp } 673 \mathrm{~K}\end{array}$ & $\begin{array}{l}\text { Fixed-bed reactor, } 2 \% \mathrm{CO} \text { and } \\
2 \% \mathrm{O}_{2} \text { in He for } \mathrm{CO} \text { oxidation, } \\
\text { flow rate of } 30 \mathrm{ml} \mathrm{min}^{-1}\end{array}$ & $\begin{array}{c}\text { The addition of transition metal oxides to } \\
\mathrm{Au} / \mathrm{Al}_{2} \mathrm{O}_{3} \text { improves the catalytic activity in } \\
\text { low temperature }(250 \mathrm{~K}) \text { of } \mathrm{CO} \text {. Measured } \\
\text { activities in } \mathrm{CH}_{4} \text { oxidation over } \\
\mathrm{Au} / \mathrm{MO}_{x} / \mathrm{Al}_{2} \mathrm{O}_{3} \text { decrease in the following } \\
\text { order: } \\
\mathrm{CuO}_{x}>\mathrm{MnO}_{x}>\mathrm{CrO}_{x}>\mathrm{FeO}_{x}>\mathrm{CoO}_{x}> \\
>\mathrm{NiO}_{x}>\mathrm{ZnO}_{x}\end{array}$ & [29] \\
\hline 5 & $\begin{array}{l}\text { Ag-based composite } \\
\text { oxides, co-precipitation } \\
\text { method, calc. temp. } \\
\text { b/w } 473 \text { to } 773 \mathrm{~K}\end{array}$ & $\begin{array}{l}25 \mathrm{mg} \text {, fixed bed quartz tube } \\
\text { reactor, } 1 \% \mathrm{CO} \text { in the air, } \\
\quad S V=45000 \mathrm{~h}^{-1}\end{array}$ & $\begin{array}{l}1: 1 \mathrm{molar} \text { ratio of } \mathrm{Ag} / \mathrm{Co} \text { and } 1: 1 \mathrm{molar} \\
\text { ratio of } \mathrm{Ag} / \mathrm{Mn} \text { calc. in air at } 473 \mathrm{~K} \\
\text { for } 3 \mathrm{~h} \text { further proposed for the selective } \\
\text { oxidation of carbon monoxide. } 1: 1 \text { molar } \\
\text { ratio of } \mathrm{Ag} / \mathrm{Co} \text { composite oxide catalyst } \\
\text { showed } 90 \% \text { of } \mathrm{CO} \text { conversion at } 453 \mathrm{~K}\end{array}$ & {$[57]$} \\
\hline
\end{tabular}


Table (continued)

\begin{tabular}{|c|c|c|c|c|}
\hline 1 & 2 & 3 & 4 & 5 \\
\hline 6 & $\begin{array}{l}\text { Supported Au catalysts, } \\
\text { different methods of } \\
\text { preparation }\end{array}$ & $\begin{array}{l}\text { Mechanism for CO oxidation, } \\
\text { deactivation and regeneration } \\
\text { are discussed in respect to the } \\
\text { available data }\end{array}$ & $\begin{array}{l}\text { Data from diff labs are collected and the } \\
\text { mechanism is developed for them. Effect } \\
\text { of water and chlorides on the activity of } \\
\text { the catalyst was also discussed }\end{array}$ & {$[58]$} \\
\hline 7 & $\begin{array}{l}\text { Supported gold catalysts } \\
\mathrm{Au} / \mathrm{SiO}_{2}, \mathrm{Au} / \mathrm{Al}_{2} \mathrm{O}_{3} \\
\mathrm{Au} / \mathrm{TiO}_{2} \text { by the gas phase } \\
\text { grafting, } \\
\text { calc. temp. of } 673 \mathrm{~K}\end{array}$ & $\begin{array}{l}100 \mathrm{mg} \text {, fixed-bed flow } \\
\text { reactor, } 1 \% \mathrm{CO} \text { in the air or } \\
1 \% \mathrm{H}_{2} \text { in air flow rate of } \\
\quad 33 \mathrm{ml} / \mathrm{min} \text {. } \\
S V=20000 \mathrm{~h}^{-1} \mathrm{ml} / \mathrm{g} \text { catalyst }\end{array}$ & $\begin{array}{l}\text { Gold deposited on } \mathrm{SiO}_{2}, \mathrm{Au} / \mathrm{SiO}_{2}-\mathrm{Al}_{2} \mathrm{O}_{3} \text {, } \\
\text { and } \mathrm{Au} / \mathrm{AC} \text { as nanoparticles has the high } \\
\text { dispersion by the gas-phase grafting than } \\
\text { by liquid-phase preparation methods }\end{array}$ & {$[51]$} \\
\hline 8 & $\begin{array}{l}\text { Co oxides, precipitation- } \\
\text { oxidation } \\
\text { method }\end{array}$ & $\begin{array}{l}\text { In-situ FTIR study of cobalt } \\
\text { oxide in a fixed-bed reactor is } \\
\text { done }\end{array}$ & $\begin{array}{l}\text { The characterizations of the cobalt oxides } \\
\text { using TPR and } \mathrm{XRD} \text { reveals that (i) the } \\
\text { reduction of } \mathrm{CoO}_{\mathrm{x}} \text { in TPR proceeds in } \\
\text { consecutive steps; and (ii) the variation in } \\
\text { oxidation of CO is interpreted with a } \\
\text { mechanism of oxygen species }\end{array}$ & [59] \\
\hline 9 & $\begin{array}{l}\text { Ce-supported Co, } \\
\text { coprecipitation, } \\
\text { impregnation methods }\end{array}$ & $\begin{array}{c}\text { Fixed-bed flow system, } \\
\text { two gas flow compositions } \\
\text { were used: (i) } 6 \% \mathrm{O}_{2} \text {; and (ii) } \\
0.5 \% \mathrm{NO}+6 \% \mathrm{O}_{2} \\
\text { the balance being helium }\end{array}$ & $\begin{array}{l}\text { All the soot has been combusted by } 673 \mathrm{~K} \text {. } \\
\text { Cobalt supported on alumina, silica, and } \\
\text { tin oxide show much lower activity due to } \\
\text { the presence of dispersed } \mathrm{Co}^{2+} \text { ions in } \\
\text { these materials. This is due to the strong } \\
\text { Co-support interaction, cobalt remains as } \\
\text { dispersed } \mathrm{Co}^{2+} \text { ions and aggregation to } \\
\text { form } \mathrm{Co}_{3} \mathrm{O}_{4} \text { microcrystallites occur only at } \\
\text { more elevated temperatures }\end{array}$ & {$[60]$} \\
\hline 10 & $\begin{array}{c}\mathrm{CoO}_{\mathrm{x}} / \mathrm{CeO}_{2} \text { catalyst, wet } \\
\text { impregnation method calc. } \\
\text { at } 923 \mathrm{~K}\end{array}$ & $\begin{array}{l}\text { Quartz reactor, } 1 \% \mathrm{CO} \text { and } \\
0.5 \% \mathrm{O}_{2} \text { in } \mathrm{N}_{2} \text { at space } \\
\text { velocity of } 30000 \mathrm{~h}^{-1}\end{array}$ & $\begin{array}{l}\text { Different cobalt loading has been prepared } \\
\text { and tested for } \mathrm{CO} \text { oxidation in } \\
\text { stoichiometric mixtures of } \mathrm{CO} \text { and } \mathrm{O}_{2} \text { and } \\
\text { it was found that the finely dispersed } \mathrm{CoO}_{x} \\
\text { species that can absorb CO mainly } \\
\text { contribute to the catalytic activity }\end{array}$ & {$[61]$} \\
\hline 11 & $\begin{array}{c}\mathrm{CoO}_{x} / \mathrm{CeO}_{2} \text {, co- } \\
\text { precipitation method. Calc. } \\
\text { temp. } 923 \mathrm{~K}\end{array}$ & $\begin{array}{c}0.1 \mathrm{~g} \text {, quartz reactor, } 1 \% \mathrm{CO} \\
\text { and } 0.5 \% \mathrm{O}_{2} \text { in } \mathrm{N}_{2} \\
S V=30000 \mathrm{~h}^{-1}\end{array}$ & $\begin{array}{l}\text { Cobalt loading of } 15 \% \text { on ceria can lead } \\
\text { to the better dispersion of cobalt oxide }\end{array}$ & [62] \\
\hline 12 & $\begin{array}{c}\mathrm{Co}_{3} \mathrm{O}_{4} \text {, formed by heating } \\
\text { a basic cobalt(II) carbonate } \\
\text { precursor, calc. temp. } \\
523 \mathrm{~K} \\
\end{array}$ & $\begin{array}{c}\text { Characterisation of the catalyst } \\
\text { is done by BET surface area } \\
\text { analysis, powder X-ray } \\
\text { diffraction }\end{array}$ & $\begin{array}{c}\text { Catalyst formed by heating a basic cobalt (II) } \\
\text { carbonate precursor in the air at } 523-573 \mathrm{~K} \\
\text { shows much greater catalytic activity than } \\
\mathrm{Co}_{3} \mathrm{O}_{4} \text { calc. at higher temperatures }\end{array}$ & {$[63]$} \\
\hline 13 & $\begin{array}{c}\mathrm{Co}_{3} \mathrm{O}_{4} \text {, precipitation } \\
\text { method, calc. in the air at } \\
1023 \mathrm{~K} \text { for } 20 \mathrm{~h}\end{array}$ & $\begin{array}{l}\text { The effect of the presence of } \\
\text { humidity and molecular } \\
\text { oxygen on the low temperature } \\
\text { oxidation of the carbon } \\
\text { monoxide on } \mathrm{Co}_{3} \mathrm{O}_{4} \text { powder } \\
\text { surface was studied }\end{array}$ & $\begin{array}{l}\text { The oxidation reaction is greatly enhanced } \\
\text { by temperature: carbon dioxide forms } \\
\text { significantly at } T \geq 323 \mathrm{~K} \text {. The presence of } \\
\text { humidity significantly decreases the } \\
\text { conversion of } \mathrm{CO} \text { to } \mathrm{CO}_{2} \text { and facilitates } \\
\text { the formation of carbonates }\end{array}$ & {$[64]$} \\
\hline 14 & $\begin{array}{l}\mathrm{Pt}-\mathrm{Co}-\mathrm{Al} \text { aerogel } \\
\text { catalysts, sol-gel method, } \\
\text { calc. temp. } 773 \mathrm{~K}\end{array}$ & $\begin{array}{c}\text { Fixed-bed micro reactor, } \\
\mathrm{H}_{2}=10000 \mathrm{ppm}, \mathrm{CO}=1000 \\
\text { ppm, } \mathrm{O}_{2}=1000 \mathrm{ppm} \text {, and } \mathrm{N}_{2} \\
\quad \text { balance, } \\
\quad S V=6600-44000 \mathrm{~h}^{-1}\end{array}$ & $\begin{array}{l}\text { Comparison of the catalysts are done by } \\
\text { preparation methods and was found that } \\
\text { the catalysts prepared by the sol-gel } \\
\text { method show larger promoting effect of } \\
\text { the cobalt addition than the catalysts } \\
\text { prepared by the conventional } \\
\text { impregnation. }\end{array}$ & {$[65]$} \\
\hline 15 & $\begin{array}{l}\text { Cobaltic oxide, } \\
\text { precipitation-oxidation, } \\
\text { impregnation and } \\
\text { hydrothermal methods, } \\
\text { calc. b/w } 673 \text { to } 773 \mathrm{~K}\end{array}$ & $\begin{array}{l}0.5 \mathrm{~g} \text {, continuous flow micro- } \\
\text { reactor, } 10 \% \mathrm{O}_{2} / \mathrm{He} \text { with } \\
4 \% \mathrm{CO} / \mathrm{He} \text { at the } \\
\text { rate of } 20 \mathrm{ml} / \mathrm{min}\end{array}$ & $\begin{array}{l}\text { Different samples of the catalyst are } \\
\text { prepared by varying cobalt. Activity of the } \\
\text { catalysts was compared in terms of surface } \\
\text { area and particle size }\end{array}$ & {$[66]$} \\
\hline 16 & $\begin{array}{l}\mathrm{Cu}-\mathrm{Zn} \text { oxide and ceria, } \\
\text { coprecipitation technique, } \\
\text { calc. temp. } 723 \mathrm{~K}\end{array}$ & $\begin{array}{c}100 \mathrm{mg} \text {, quartz tube reactor, } \\
3.6 \% \mathrm{CO}-21 \% \mathrm{O}_{2}-\mathrm{Ar} \text {, Flow } \\
\text { rate of } 1 \mathrm{l} / \mathrm{min}, S V \text { varies from } \\
15000 \text { to } 150000 \mathrm{~h}^{-1}\end{array}$ & $\begin{array}{l}\text { It was shown that aged CuO- } \mathrm{ZnO} \text { catalyst } \\
\text { containing } 60 \% \mathrm{CuO} \text { and } 40 \% \mathrm{ZnO} \text { is } \\
\text { highly active for the complete oxidation of } \\
\mathrm{CO} \text { to } \mathrm{CO}_{2} \text { at ambient temperature. The }\end{array}$ & {$[67]$} \\
\hline
\end{tabular}


Table (continued)

\begin{tabular}{|c|c|c|c|c|}
\hline 1 & 2 & 3 & 4 & 5 \\
\hline & & & $\begin{array}{l}\text { catalytic activity of the co-precipitated CuO- } \\
\mathrm{ZnO} \text { can also be improved significantly by } \\
\text { the addition of } \mathrm{CeO}_{2} \text { during the precipitation } \\
\text { without the aging process }\end{array}$ & \\
\hline 17 & $\begin{array}{l}\text { Cu-Mn, sol-gel method, } \\
\text { calc. temp. } 673 \mathrm{~K}\end{array}$ & $\begin{array}{c}100 \mathrm{mg} \text {, fixed-bed flow } \\
\text { reactor, flow rate of } \\
30000 \mathrm{ml} \mathrm{h}^{-1} \mathrm{~g}^{-1}, 1 \% \mathrm{CO}, \\
4.88 \% \text { synthetic air, } 20 \text { vol } \% \\
\mathrm{CO}_{2} \text { in hydrogen }\end{array}$ & $\begin{array}{l}\text { The influence of composition and } \\
\text { calcination temperature }(T c) \text { on the } \\
\text { catalytic activity was shown for the } \\
\text { oxidation of CO copper manganese } \\
\text { oxides. Catalyst calcined at } 673 \mathrm{~K} \text { and at } \\
\text { composition of } 20 \% \mathrm{Cu} \text { showed } \\
\text { maximum conversion }(60 \%) \text { of } \mathrm{CO}\end{array}$ & {$[68]$} \\
\hline 18 & $\begin{array}{c}\text { Cobalt catalysts }(5 \% \text { as } \\
\text { metal Co loading on } \mathrm{SiO}_{2} \text {, } \\
\left.\mathrm{Al}_{2} \mathrm{O}_{3} \text { and } \mathrm{TiO}_{2}\right) \text {, incipient } \\
\text { wetness impregnation } \\
\text { method, calc. in air at } \\
673 \mathrm{~K} \text { for } 4 \mathrm{~h}\end{array}$ & $\begin{array}{l}40 \mathrm{mg} \text {, continuous flow micro- } \\
\text { reactor, } 10 \% \mathrm{O}_{2} / \mathrm{He} \text { with } \\
4 \% \mathrm{CO} / \mathrm{He}\end{array}$ & $\begin{array}{l}\text { The activities of the catalysts are described } \\
\text { in terms of adsorption of } \mathrm{CO} \text { and } \mathrm{CO}_{2} \\
\text { molecules. The reaction between adsorbed } \\
\mathrm{CO} \text { and lattice oxygen of cobalt oxide } \\
\text { while both strong adsorption of } \mathrm{CO} \text { on } \\
\mathrm{TiO}_{2} \text { and } \mathrm{CO}_{2} \text { on cobalt oxide leads to } \\
\text { affect the activity }\end{array}$ & [69] \\
\hline 19 & $\begin{array}{c}\mathrm{CoO}_{\mathrm{x}} / \mathrm{Al}_{2} \mathrm{O}_{3} \text { deposition } \\
\text { oxidation-precipitation } \\
\text { method, calc. temp. } 383 \mathrm{~K}\end{array}$ & $\begin{array}{l}0.15 \mathrm{~g} \text {, isothermal plug-flow } \\
\text { reactor, flow rate of } 4.4 \mathrm{l} / \mathrm{h} \text {, } \\
\quad S V=22000 \mathrm{~h}^{-1}\end{array}$ & $\begin{array}{l}\text { Very high activity of the catalyst towards } \\
\text { ozone decomposition even at } 233 \mathrm{~K}\end{array}$ & {$[70]$} \\
\hline 20 & $\begin{array}{l}\mathrm{Co} / \mathrm{ZrO}_{2} \text {, impregnation, } \\
\text { Calcinations temp } 773 \mathrm{~K}\end{array}$ & $\begin{array}{l}200 \mathrm{mg} \text {, fixed bed flow reactor, } \\
\text { varying gas concentrations of } \\
\left(\mathrm{CO}, \mathrm{O}_{2}, \mathrm{He}\right) \text {. Flow rate is } \\
45 \mathrm{~cm}^{3} / \mathrm{min} \text { and } S V=35000 \mathrm{~h}^{-1}\end{array}$ & $\begin{array}{l}100 \% \text { conversion of } \mathrm{CO} \text { to } \mathrm{CO}_{2} \text { could } \\
\text { occur even at room temperature }\end{array}$ & [71] \\
\hline 21 & $\begin{array}{c}\mathrm{Co} /\left(\mathrm{ZrO}_{2}, \mathrm{CeO}_{2}, \mathrm{SiO}_{2},\right. \\
\left.\mathrm{Al}_{2} \mathrm{O}_{3} \text {, and } \mathrm{TiO}_{2}\right) \text { prepared } \\
\text { by wet impregnation, calc. } \\
\text { temp. of } 773 \mathrm{~K} \\
\end{array}$ & $\begin{array}{c}100 \mathrm{mg} \text {, quartz U-tube reactor } \\
\text { with flow rate of } 50 \mathrm{ml} / \mathrm{min} \\
\text { having feed of } 1 \% \mathrm{O}_{2}, 1 \% \mathrm{CO} \\
\text { and } 60 \% \mathrm{H}_{2} \text { in } \mathrm{He}\end{array}$ & $\begin{array}{l}\mathrm{Co} / \mathrm{ZrO}_{2} \text { catalyst had the highest } \mathrm{CO} \\
\text { oxidation conversion of } 94 \% \text { at } 448 \mathrm{~K} \\
\text { from the rest of supports }\end{array}$ & [72] \\
\hline 22 & $\begin{array}{c}\mathrm{CoO}_{x} / \mathrm{ZrO}_{2} \text {, incipient } \\
\text { wetness, impregnation } \\
\text { technique, calc. temp. } \\
773 \mathrm{~K}\end{array}$ & $\begin{array}{c}200 \mathrm{mg} \text {, fixed bed reactor, flow } \\
\text { rate } 50 \mathrm{~cm}^{3}(\mathrm{STP}) / \mathrm{min} \text {, } \\
1 \% \mathrm{CO}, 1 \% \mathrm{O}_{2}, 60 \% \mathrm{H}_{2} \text {, and } \\
\text { balance } \mathrm{He}, \\
S V=39000 \mathrm{~h}^{-1}\end{array}$ & $\begin{array}{c}\text { Increasing GHSV causes decrease in CO } \\
\text { conversion and an increase in } \mathrm{O}_{2} \\
\text { selectivity to } \mathrm{CO}_{2}\end{array}$ & {$[73]$} \\
\hline 23 & $\begin{array}{c}\text { Nanocrystalline } \mathrm{Co}_{3} \mathrm{O}_{4}, \\
\text { calc. at } 473,523,573 \text { or } \\
673 \mathrm{~K} \text { which is formed by } \\
\text { heating a basic cobalt(II) } \\
\text { carbonate precursor in air } \\
\text { at } 523-573 \mathrm{~K}\end{array}$ & $\begin{array}{l}\text { DSC, TGA, XRD, XPS, BET } \\
\text { isotherms, DR/FT-IR } \\
\text { spectrometry of the catalyst } \\
\text { have been studied }\end{array}$ & $\begin{array}{c}\text { In the proposed mechanism } \mathrm{CO} \text { is } \\
\text { adsorbed on Co atoms in a low oxidation } \\
\text { state, presumably } \mathrm{Co}(\mathrm{II}) \text {. The adsorbed } \\
\mathrm{CO} \text { interacts with an oxygen atom bonded } \\
\text { to a neighbouring Co(III) atom in a } \\
\text { strongly exothermic reaction, forming } \\
\text { vibrationally excited } \mathrm{CO}_{2}\end{array}$ & [74] \\
\hline 24 & $\begin{array}{l}\text { Co promoted } \mathrm{Cu}-\mathrm{Mn} \text { oxide } \\
\text { catalysts, } \\
\text { co-precipitation, } \\
\text { calc. temp. } 688 \mathrm{~K}\end{array}$ & $\begin{array}{l}\text { Catalysts containing } 0,1 \text { and } \\
5 \text { mol \% Co were tested for the } \\
\text { oxidation of CO in a fixed bed } \\
\text { reactor, oxidation at } 298 \mathrm{~K} \\
\text { using } 5000 \mathrm{ppm} \mathrm{CO} \text { in the air, }^{S V=33000 \mathrm{~h}^{-1}}\end{array}$ & $\begin{array}{l}\text { Low levels of cobalt doping ( } 1 \mathrm{wt} \%) \text { of } \\
\text { copper manganese oxide enhance its } \\
\text { activity for carbon monoxide oxidation } \\
\text { under ambient conditions }\end{array}$ & {$[75]$} \\
\hline 25 & $\begin{array}{c}\text { Mesoporous } \mathrm{Co}_{3} \mathrm{O}_{4}-\mathrm{CeO}_{2} \\
\text { and } \mathrm{Pd} / \mathrm{Co}_{3} \mathrm{O}_{4}-\mathrm{CeO}_{2}, \\
\text { surfactant-template } \\
\text { method, promoted by } \mathrm{Pd} \\
(0.5 \mathrm{wt} \%), \\
\text { calc. temp. } 773 \mathrm{~K}\end{array}$ & $\begin{array}{c}600 \mathrm{mg} \text {, fixed-bed quartz } \\
\text { tubular reactor, feed gas of } \\
1 \% \mathrm{CO}, 5 \% \mathrm{O}_{2}-\mathrm{N}_{2} \text {, flow rate } \\
\text { of } 100 \mathrm{ml} \cdot \mathrm{min}^{-1} ; \\
S V=10000 \mathrm{ml} \cdot \mathrm{g}^{-1} \cdot \mathrm{h}^{-1}\end{array}$ & $\begin{array}{l}\text { Pd prominently enhances both the } \\
\text { reduction and oxidation performance of } \\
\text { the catalysts, due to hydrogen or oxygen } \\
\text { spill over }\end{array}$ & [76] \\
\hline 26 & $\begin{array}{l}\mathrm{CeO}_{2} / \mathrm{Co}_{3} \mathrm{O}_{4} \text { prepared by } \\
\text { the impregnation method, } \\
\text { calc. temp. } 473 \mathrm{~K}\end{array}$ & $\begin{array}{l}0.5 \mathrm{~g} \text {, continuous flow micro- } \\
\text { reactor, flow rate of } \\
20 \mathrm{ml} \cdot \mathrm{min}^{-1} \text { contains } 4 \% \mathrm{CO} / \mathrm{He} \\
\end{array}$ & $\begin{array}{l}\text { Ce20/R230, increased surface area of } \\
\text { cobaltic oxide, } 100 \% \text { conversion of Co } \\
\text { was obtained at } 443 \mathrm{~K}\end{array}$ & [77] \\
\hline 27 & $\begin{array}{l}\text { Effect of } \mathrm{Cu} \text { on alumina } \\
\text { supported Au catalysts, } \\
\text { deposition precipitation }\end{array}$ & $\begin{array}{l}200 \mathrm{mg} \text {, glass micro reactor, } \\
1 \% \mathrm{CO} ; 0.5-1.5 \% \mathrm{O}_{2} ; 30 \% \\
\mathrm{H}_{2} ; 0-30 \% \mathrm{CO}_{2} ; 0-10 \% \mathrm{H}_{2} \mathrm{O}\end{array}$ & $\begin{array}{l}\text { Interaction between } \mathrm{Cu} \text { and } \mathrm{Au} \text { seemed to } \\
\text { be able to modify the catalytic properties } \\
\text { of } \mathrm{Au} \text { active sites for } \mathrm{CO} \text { oxidation. } 100 \%\end{array}$ & {$[24]$} \\
\hline
\end{tabular}


Table (continued)

\begin{tabular}{|c|c|c|c|c|}
\hline 1 & 2 & 3 & 4 & 5 \\
\hline & $\begin{array}{c}\text { method, } \\
\text { calc. temp. } 773 \mathrm{~K}\end{array}$ & $\begin{array}{c}\text { and He balance, } \\
\text { flow rate } 100 \mathrm{ml} \cdot \mathrm{min}^{-1}\end{array}$ & $\begin{array}{c}\text { conversion was achieved with } 2.5 \% \\
\mathrm{Au}-0.5 \% \mathrm{Cu} / \mathrm{Al}_{2} \mathrm{O}_{3} \text { at } 323 \mathrm{~K}\end{array}$ & \\
\hline 28 & Gold nanoparticle & $\begin{array}{l}\text { The glass reactor was used for } \\
\text { the study of the catalyst by } \\
\text { varying the total surface area of } \\
\text { a gold catalyst: } \\
3.36,18.48,33.6 \mathrm{~m}^{3} \text {; CO gas } \\
\text { concentration: } 10 \%, 30 \% \text {, } \\
50 \% \text {; relative humidity: } 9 \% \text {, } \\
50 \%, 100 \% \text { respectively. }\end{array}$ & $\begin{array}{l}\text { The results indicate that the conversion } \\
\text { efficiency of } \mathrm{CO} \text { was high when the ratio } \\
\text { of } \mathrm{CO} \text { and } \mathrm{O}_{2} \text { was close to } 1: 1 \text {. The gas } \\
\text { concentration is the most important factor, } \\
\text { followed by the weight of gold catalyst, } \\
\text { followed by the relative humidity }\end{array}$ & {$[78]$} \\
\hline 29 & $\begin{array}{c}\mathrm{Cu}-\mathrm{Mn} \text { oxide, redox } \\
\text { method, calc. temp. } 573 \mathrm{~K}\end{array}$ & $\begin{array}{c}100 \mathrm{mg} \text {, quartz tubular fixed } \\
\text { bed flow reactor, } 1 \% \mathrm{CO} \\
2 \% \mathrm{O}_{2} \text { and } 5 \% \mathrm{~N}_{2} \text { in } \mathrm{He} . \\
S V=12000-35000 \mathrm{ml} \cdot \mathrm{h}^{-1} \cdot \mathrm{g}_{\text {cat }}{ }^{-1}\end{array}$ & $\begin{array}{l}\text { The catalytic performance of catalysts } \\
\text { prepared using the redox method } \\
\text { compared with a commercial Hopcalite } \\
\text { catalyst. The optimum copper loading was } \\
\text { determined to be } 9 \% \text { of the manganese } \\
\text { content at ambient temperature }\end{array}$ & {$[79]$} \\
\hline 30 & $\begin{array}{l}\mathrm{Cu}-\mathrm{Mn} \text { oxide modified by } \\
\mathrm{Au} \text {, co-precipitation } \\
\text { method, calc. temp. } 688 \mathrm{~K}\end{array}$ & $\begin{array}{l}\text { Fixed bed micro reactor, space } \\
\text { velocity of } 12000 \mathrm{~h}^{-1} \text {, flow rate } \\
\text { of } 15 \mathrm{ml} \cdot \mathrm{min}^{-1}\end{array}$ & $\begin{array}{l}\text { The addition of Au to an active hopcalite } \\
\text { catalyst, using a deposition-precipitation } \\
\text { procedure, leads to a marked improvement } \\
\text { in activity towards CO oxidation }\end{array}$ & {$[80]$} \\
\hline 31 & $\begin{array}{l}\mathrm{Co} / \mathrm{CeO}_{2} \text { nanoparticles, } \\
\text { incipient wetness } \\
\text { impregnation, } \\
\text { calc. at } 673 \mathrm{~K}\end{array}$ & $\begin{array}{c}100-200 \mathrm{mg}, 1 \% \mathrm{CO}, 1 \% \mathrm{O}_{2} \\
10 \% \mathrm{H}_{2} \text { and balance helium. } \\
\text { Characterisation done by TEM, } \\
\text { LRS etc. }\end{array}$ & $\begin{array}{l}\text { Oxidation was done at three temperatures } \\
\text { and it was found that below } 448 \mathrm{~K}, \mathrm{CO} \\
\text { oxidation is dominant between } 448 \text { and } \\
548 \mathrm{~K}, \mathrm{CO} \text { oxidation competes with } \mathrm{H}_{2} \\
\text { combustion and above } 548 \mathrm{~K} \text {, methanation } \\
\text { dominates. The high-surface area } 10 \% \\
\mathrm{CoO}_{\mathrm{x}} / \mathrm{CeO}_{2} \text { catalyst is highly effective for } \\
\text { the preferential oxidation of } \mathrm{CO} \text { in } \mathrm{H}_{2} \text { rich } \\
\text { feed }\end{array}$ & {$[81]$} \\
\hline 32 & $\begin{array}{l}\text { Cu-Mn oxides, redox } \\
\text { method, } \\
\text { calc. temp. } 573 \mathrm{~K}\end{array}$ & $\begin{array}{c}100 \mathrm{mg} \text {, continuous flow fixed } \\
\text { bed quartz tubular reactor, } \\
1 \% \mathrm{CO}, 1 \% \mathrm{O}_{2} \\
60 \% \mathrm{H}_{2} \text { balanced with } \mathrm{N}_{2}\end{array}$ & $\begin{array}{l}\text { Catalyst having the copper/manganese } \\
\text { ratio of } 0.06 \text { shows the maximum } \\
\text { conversion at } 323 \mathrm{~K} \text {. The high catalytic } \\
\text { activity was attributed to a combination of } \\
\text { factors including the high surface areas, } \\
\text { low crystallinity, compositional } \\
\text { homogeneity, low activation energy, and } \\
\text { the presence of readily available lattice } \\
\text { oxygen for CO oxidation }\end{array}$ & {$[82]$} \\
\hline 33 & $\begin{array}{c}\mathrm{CoO}_{\mathrm{x}} / \gamma-\mathrm{Al}_{2} \mathrm{O}_{3}, \text { wet } \\
\text { impregnation, calc. temp. } \\
1023 \mathrm{~K}\end{array}$ & $\begin{array}{c}50 \mathrm{mg} \text {, microreactor, } \\
1.6 \% \mathrm{CO}, 20.8 \% \mathrm{O}_{2} \\
\text { and } 77.6 \% \mathrm{~N}_{2} \\
S V=72000 \mathrm{ml} / \mathrm{g} \cdot \mathrm{h}\end{array}$ & $\begin{array}{c}\mathrm{CoO} / \gamma-\mathrm{Al}_{2} \mathrm{O}_{3} \text { loaded with } \\
61.2 \mathrm{mmol} /\left(100 \mathrm{~m}^{2} \gamma-\mathrm{Al}_{2} \mathrm{O}_{3}\right) \text { is more } \\
\text { active than } \mathrm{Co}_{3} \mathrm{O}_{4} / \gamma-\mathrm{Al}_{2} \mathrm{O}_{3} \text { catalysts for } \mathrm{CO} \\
\text { oxidation }\end{array}$ & {$[83]$} \\
\hline 34 & $\begin{array}{l}\mathrm{CoO}_{\mathrm{x}} / \mathrm{CeO}_{2} \text {, wet } \\
\text { impregnation method, } \\
\text { calc. temp. } 673 \mathrm{~K}\end{array}$ & $\begin{array}{c}50 \mathrm{mg} \text {, fixed bed reactor, flow } \\
\text { rate } 130 \mathrm{~cm}^{3} / \mathrm{min}, 2 \% \mathrm{CO} \\
2 \% \mathrm{O}_{2}, \text { balance He}^{3} \\
S V=15000 \mathrm{~cm}^{3} \cdot\left(\mathrm{g} \mathrm{cat}^{-1}\right) \cdot \mathrm{h}^{-1}\end{array}$ & $\begin{array}{c}\text { Higher Co loadings favoured CO } \\
\text { oxidation at low temp. }(\mathrm{T} \leq 423 \mathrm{~K}) \text { under } \\
\text { dry conditions }\end{array}$ & {$[84]$} \\
\hline 35 & $\begin{array}{l}\text { Nanosized Fe-Co mixed } \\
\text { oxide prepared by co- } \\
\text { precipitation method, calc. } \\
\text { temp. } 673,773 \text { and } 873 \mathrm{~K} \\
\quad \text { for } 4 \mathrm{~h} \text { in air }\end{array}$ & $\begin{array}{l}100 \mathrm{mg} \text {, bed quartz micro- } \\
\text { reactor, } 2 \% \mathrm{CO}, 20 \% \mathrm{O}_{2} \text { and } \\
10 \% \mathrm{~N}_{2} \text { balanced with } \mathrm{He} \\
\text { GHSV of } 60000 \mathrm{ml} / \mathrm{g} \cdot \mathrm{h}\end{array}$ & $\begin{array}{l}\text { Addition of Co to iron oxide causes an } \\
\text { increase in CO conversion. Results indicate } \\
\text { that calc. at lower temperatures and/or } \\
\text { introducing oxidative pretreatment has an } \\
\text { extensive role to increasing activity of CO } \\
\text { oxidation on Fe-Co mixed oxide catalysts }\end{array}$ & {$[85]$} \\
\hline 36 & $\begin{array}{l}\mathrm{Co} / \mathrm{Al}_{2} \mathrm{O}_{3} \text {, impregnation } \\
\text { and sol-gel, } 623 \mathrm{~K}\end{array}$ & $\begin{array}{l}200 \mathrm{mg} \text {, tubular flow reactor, } \\
8 \mathrm{ml} / \mathrm{min} \mathrm{CO} \text { and } 4 \mathrm{ml} / \mathrm{min} \mathrm{O}_{2}, \\
\text { which was balanced with He to } \\
\text { a total flow rate of } 50 \mathrm{ml} / \mathrm{min}\end{array}$ & $\begin{array}{l}\text { Catalyst prepared by impregnation } \\
\text { methods has the high activity. }\end{array}$ & {$[25]$} \\
\hline 37 & $\begin{array}{l}\mathrm{Co}_{3} \mathrm{O}_{4} / \mathrm{Al}_{2} \mathrm{O}_{3} \text {, precipitation } \\
\text { method, calc. at } 823 \mathrm{~K}\end{array}$ & $\begin{array}{l}\text { Vertical quartz tube reactor, } \\
6 \mathrm{vol} \% \mathrm{O}_{2} / \text { argon gas mixture }\end{array}$ & $\begin{array}{l}\text { The preoxidised catalyst shows the higher } \\
\text { activity for CO oxidation than the } \\
\text { prereduced catalyst }\end{array}$ & {$[26]$} \\
\hline
\end{tabular}


Table (continued)

\begin{tabular}{|c|c|c|c|c|}
\hline 1 & 2 & 3 & 4 & 5 \\
\hline 38 & $\begin{array}{l}\mathrm{Co} / \mathrm{Al}_{2} \mathrm{O}_{3} \text {, deposition- } \\
\text { precipitation, incipient- } \\
\text { wetness impregnation, } \\
\text { oxidative decomposition, } \\
\text { calc. at } 623 \text { and } 773 \mathrm{~K} \text {, } \\
\text { respectively }\end{array}$ & $\begin{array}{c}0.5 \mathrm{~g}, \text { quartz } \mathrm{U} \text {-tube } \\
\text { microreactor, } 100 \mathrm{ml} / \mathrm{min} \text { of } \\
0.095 \% \mathrm{NO}, 0.1 \% \mathrm{C}_{3} \mathrm{H}_{6} \\
5 \% \mathrm{O}_{2} \text {, and } 1.7 \% \mathrm{H}_{2} \mathrm{O} \\
\text { balanced with } \mathrm{He}\end{array}$ & $\begin{array}{l}\mathrm{Co} / \mathrm{Al}_{2} \mathrm{O}_{3} \text { catalysts have been found to be } \\
\text { active and stable in NO SCR reaction }\end{array}$ & [86] \\
\hline 39 & $\begin{array}{c}\mathrm{Co} / \mathrm{Al}_{2} \mathrm{O}_{3} \text {, impregnation } \\
\text { method, calc. temp. } \\
1373 \mathrm{~K}\end{array}$ & $\begin{array}{c}0.3 \mathrm{~g}, \mathrm{U} \text {-shaped quartz glass } \\
\text { reactor, } 750 \text { ppm of } \mathrm{NO}, \\
680 \mathrm{ppm}_{3} \mathrm{H}_{6}, 4 \% \mathrm{O}_{2} \text { and the } \\
\text { rest was } \mathrm{N}_{2}\end{array}$ & $\begin{array}{l}\mathrm{Co} / \mathrm{Al}_{2} \mathrm{O}_{3} \text { has the high performance } \\
\text { prepared by sol-gel than impregnation }\end{array}$ & [87] \\
\hline 40 & $\begin{array}{l}\mathrm{CoO}_{x} \text { catalysts, sol-gel } \\
\text { method, calc. temp. } \\
923 \mathrm{~K}\end{array}$ & $\begin{array}{l}100 \mathrm{mg} \text {, fixed bed flow reactor, } \\
1000 \mathrm{ppm} \text { of } \mathrm{NO}, 1000 \text { ppm of } \\
\mathrm{C}_{3} \mathrm{H}_{6}, 5 \text { vol } \% \mathrm{O}_{2} \text {, balance He }\end{array}$ & $\begin{array}{l}\mathrm{CoO}_{x} / \mathrm{Al}_{2} \mathrm{O}_{3}-\mathrm{BaO} \text { catalysts are more stable } \\
\text { and more active in NO SCR, than the } \\
\text { corresponding ones supported on alumina }\end{array}$ & [88] \\
\hline 41 & $\begin{array}{l}\mathrm{CoO} / \gamma-\mathrm{Al}_{2} \mathrm{O}_{3} \text {, deposition } \\
\text { precipitation, calc. temp. } \\
\qquad 923 \mathrm{~K}\end{array}$ & $\begin{array}{l}200 \mathrm{mg} \text {, continuous flow } \\
\text { fixed-bed microreactor, } \\
0.1 \% \mathrm{v} / \mathrm{v} \mathrm{NO}, 0.1 \% \text { v/v } \mathrm{C}_{3} \mathrm{H}_{6} \\
10 \% \mathrm{O}_{2} \text { with } \mathrm{N}_{2} \text { as balance }\end{array}$ & $\begin{array}{l}\text { The increase of Co loading over } 5 \% \\
\text { favoured the formation of supported } \\
\text { Co(III) oxospecies on the support surface }\end{array}$ & [89] \\
\hline 42 & $\begin{array}{c}\text { Co-based alumina } \\
\text { catalysts, co-precipitation, } \\
1073 \mathrm{~K}\end{array}$ & $\begin{array}{c}0.5 \mathrm{~g} \text {, fixed-bed stainless steel } \\
\text { reactor, } 1000 \text { ppm } \mathrm{NO} \\
1000 \mathrm{ppm} \mathrm{C}_{3} \mathrm{H}_{8} \text { or } \mathrm{C}_{3} \mathrm{H}_{6} \\
5 \% \mathrm{O}_{2} \text {, and } \mathrm{He}\end{array}$ & $\begin{array}{l}\text { Effect of additive metals can be described } \\
\text { as follows: } \\
\text { CoZn }>\mathrm{CoAg}, \mathrm{CoNi}>\mathrm{CoCu}>\mathrm{CoFe} \text {. } \\
\text { Maximum NO conversion of } 96 \% \text { was } \\
\text { achieved at the reaction temperatures of } \\
723 \mathrm{~K} \text { on } 8 \mathrm{Co} 4 \mathrm{ZnA} 800 \text { sample }\end{array}$ & [90] \\
\hline 43 & $\begin{array}{c}\mathrm{CoO}_{\mathrm{x}} / \mathrm{Al}_{2} \mathrm{O}_{3}, \mathrm{co}- \\
\text { precipitation, sol-gel, } \\
\text { incipient wetness } \\
\text { impregnation and solid } \\
\text { dispersion, } \\
\text { calc. temp. } 723 \mathrm{~K}\end{array}$ & $\begin{array}{c}\text { Continuous flow fixed-bed } \\
\text { microreactor, } 1000 \text { ppm NO, } \\
1000 \mathrm{ppm}_{3} \mathrm{H}_{8} \text { and } 10 \% \mathrm{O}_{2}, \\
\text { helium as balance gas, } \\
\text { GHSV }=10000 \mathrm{~h}^{-1}\end{array}$ & $\begin{array}{l}\text { The optimized } \mathrm{CoO}_{\mathrm{x}} / \mathrm{Al}_{2} \mathrm{O}_{3} \text { catalysts have } \\
\text { been found to be active in SCR of NO by } \\
\mathrm{C}_{3} \mathrm{H}_{8} \text {. The SCR activity increases with an } \\
\text { increase in the strength of cobalt-alumina } \\
\text { interactions in the catalysts }\end{array}$ & {$[91]$} \\
\hline 44 & $\begin{array}{c}\mathrm{CoO} / \mathrm{A}_{2} \mathrm{O}_{3}, \mathrm{FeO} / \mathrm{Al}_{2} \mathrm{O}_{3} \\
\text { impregnation, sol-gel } \\
\text { method, calc. temp. } \\
873 \mathrm{~K}\end{array}$ & $\begin{array}{l}0.2 \mathrm{~g}, \text { fixed bed flow reactor, } \\
\mathrm{NO}, \mathrm{NO}_{2}, \mathrm{O}_{2} \text { and } \mathrm{C}_{3} \mathrm{H}_{6} \text { diluted } \\
\text { in helium; } \\
\text { flow rate is } 62 \mathrm{~cm}^{3} / \mathrm{min}\end{array}$ & $\begin{array}{l}\text { Cobalt/aluminate species are much more } \\
\text { stable than iron/aluminate }\end{array}$ & [92] \\
\hline 45 & $\begin{array}{l}\text { Co-Beta, calc. temp. } \\
823 \mathrm{~K}\end{array}$ & $4 \mathrm{ml}$, fixed-bed flow reactor & $\begin{array}{l}\text { Highly-dispersed cobalt is essential for the } \\
\text { high activity and selectivity for } \mathrm{NO}_{\mathrm{x}} \\
\text { reduction }\end{array}$ & [93] \\
\hline 46 & $\begin{array}{l}\mathrm{Co}_{3} \mathrm{O}_{4} / \gamma-\mathrm{Al}_{2} \mathrm{O}_{3} \\
\text { combination of wetness } \\
\text { impregnation and } \\
\text { subsequent combustion, } \\
\text { calc. temp. } 873 \mathrm{~K} \\
\end{array}$ & $\begin{array}{l}1.0 \mathrm{ml} \text {, quartz tubular fixed- } \\
\text { bed reactor, space velocity of } \\
\text { about } 15000 \mathrm{~h}^{-1}\end{array}$ & $\begin{array}{l}\text { Combustion-synthesized } \mathrm{Co}_{3} \mathrm{O}_{4} / \gamma-\mathrm{Al}_{2} \mathrm{O}_{3} \\
\text { catalysts retained better activity than the } \\
\text { catalyst prepared by the thermal } \\
\text { decomposition of cobalt nitrate }\end{array}$ & [94] \\
\hline 47 & $\begin{array}{l}\text { Cobalt/alumina, } \\
\text { impregnation, } \\
\text { calc. temp. } 573 \mathrm{~K}\end{array}$ & $\begin{array}{l}50 \mathrm{mg} \text {, continuous flow fixed- } \\
\text { bed micro-reactor, } \\
250 \text { ppm } \mathrm{C}_{6} \mathrm{H}_{6}, 20 \% \mathrm{O}_{2} \text { with } \\
\text { nitrogen as a balance }\end{array}$ & $\begin{array}{l}\text { It was found that two parameters influence } \\
\text { the catalytic activity; the dispersion and } \\
\text { the characteristics of the 'active species' }\end{array}$ & [95] \\
\hline 48 & $\begin{array}{l}\text { Cobalt oxide, wet } \\
\text { impregnation method, } \\
\text { calc. temp. } 773 \mathrm{~K}\end{array}$ & $\begin{array}{l}250 \mathrm{mg} \text {, fixed bed quartz } \\
\text { reactor tube, } 8000 \mathrm{ppm} \\
\text { propane in air with a total flow } \\
\text { rate of } 50 \mathrm{ml} / \mathrm{min}\end{array}$ & $\begin{array}{l}\text { Total conversion has been attained at a } \\
\text { reaction temperature as low as } 523 \mathrm{~K}\end{array}$ & [96] \\
\hline 49 & $\begin{array}{l}\text { Ce-Pt/ } / \mathrm{Al}_{2} \mathrm{O}_{3} \\
\text { sol-gel method, } \\
\text { calc. temp. } 673 \mathrm{~K}\end{array}$ & $\begin{array}{c}140 \mathrm{mg} \text {, tubular fixed bed } \\
\text { reactor, } 19.38 \% \text { of } \mathrm{O}_{2}, \\
77.52 \% \text { of } \mathrm{N}_{2}, 3 \% \text { of } \mathrm{H}_{2} \mathrm{O} \text { and } \\
0.1 \% \text { of VOC }\end{array}$ & $\begin{array}{l}\text { Results reveal that the presence of ceria } \\
\text { affects the reducibility of the material } \\
\text { surface, show an increase of the oxygen } \\
\text { storage capacity when increasing the ceria } \\
\text { loading }\end{array}$ & [97] \\
\hline 50 & $\begin{array}{l}\mathrm{Pt}, \mathrm{Pd} \text { and } \mathrm{Pt}+\mathrm{Pd} / \gamma-\mathrm{Al}_{2} \mathrm{O}_{3} \\
\text { and on } \mathrm{TiO}_{2} \text {, impregnation } \\
\text { method, calc. temp. } 593 \mathrm{~K}\end{array}$ & $\begin{array}{l}\text { Stainless steel tube reactor, } \\
\qquad G H S V=21000 \mathrm{~h}^{-1}\end{array}$ & $\begin{array}{c}\mathrm{Pd} / \mathrm{Al}_{2} \mathrm{O}_{3} \text { is a superior catalyst and has } \\
\text { shown the higher activity towards methane } \\
\text { combustion }\end{array}$ & [98] \\
\hline 51 & $\begin{array}{c}\text { Pt catalysts, impregnation } \\
\text { method, } \\
\text { calc. temp. } 873 \mathrm{~K}\end{array}$ & $\begin{array}{l}\text { 20-60 mg, quartz reactor, } \\
250 \text { ppm VOC, } \\
S V=30000-400000 \mathrm{~h}^{-1}\end{array}$ & $\begin{array}{l}\text { Pt for benzene and ethylacetate oxidation } \\
\text { is enhanced, when it is supported on } \mathrm{TiO} \\
\text { carriers doped with } \mathrm{W}^{6+} \text { cations }\end{array}$ & [99] \\
\hline
\end{tabular}


As seen from the Table, extensive amount of work has been done on cobalt catalyst. Oxidation is not the only field where it has been studied but there are other promising fields where it has been explored such as medicine [100-103], Fischer-Tropsch synthesis [104-105], pharmaceutical industry [106-107], food [108-109], agriculture [110-111]. Besides the exploration of cobalt in many fields it is also regarded as cheap or economical [112] and easily available compound. Recently cobalt has been reported for oxidation studies [113-118], cobalt oxide [119-120] catalyst due to its unique activity for CO oxidation. Past experience also revealed that the oxidation activity of these base metal oxide catalysts can be prominently enhanced by the several metal oxides such as ceria [72], zirconium dioxide, silicon dioxide, aluminium dioxide, titanium dioxide [51], gold [57], copper manganese oxide [23]. Nowadays, more and more studies are focusing on the catalysts with the combination of noble metal and base metal oxides for oxidation applications [80, 27]. It has also been shown that calcinations in the presence of oxygen yields a highly reactive catalyst for the room temperature oxidation of $\mathrm{CO}$ with observed light-off temperature as low as $210 \mathrm{~K}$ [56, 121]. C.-B. Wang and his co-workers have done considerable amount of work on cobalt as a catalyst for the oxidation of carbon monoxide. Different supports are being used and characterised for the betterment of the catalyst, i.e. for the conversion of $\mathrm{CO}$. With the increase in the oxidation state of cobalt, the activity of the catalyst decreases [59]. Again in 2005, different methods of catalyst preparation were adopted and hence correlations between a catalytic activity and surface area properties are obtained. It was concluded that pre-treatment of the catalyst with $\mathrm{H}_{2}$ can reduce the conversion temperature [66]. Different supports, i.e. $5 \%$ as the metal Co loading on $\mathrm{SiO}_{2}, \mathrm{Al}_{2} \mathrm{O}_{3}$ and $\mathrm{TiO}_{2}$ were studied and their catalytic activities were tested. $\mathrm{Co} / \mathrm{SiO}_{2}$ showed $100 \%$ conversion at $453 \mathrm{~K}$ followed by $95 \%$ for $\mathrm{Co} / \mathrm{Al}_{2} \mathrm{O}_{3}$ and $25 \%$ for $\mathrm{Co} / \mathrm{TiO}_{2}$ [56]. Other transition methods [21, 52, 59, 63, $66,69,77]$ were also studied by varying their compositions. Review of copper chromite catalys for $\mathrm{CO}$ oxidation $[45,83]$ published a review article on VOCs. Hence their effects have been studied accordingly. Catalysts of different composition with ceria have been prepared and characterised. According to the results, the optimum loading of ceria is $20 \%$. It exhibits the highest surface area and the best catalytic activity toward $\mathrm{CO}$ oxidation $\left(T_{50 \%}=361 \mathrm{~K}\right)$ among those catalysts [77].

\section{Conclusions}

On the basis of the above study that was made primarily on carbon monoxide with many other hazardous materials as well, we can sum up the results. We have enough spoken about various parameters such as sources of the pollutants, their causes, their effects on humans and things and at the end we described the removal of these compounds by the uses of different catalyst. The catalysts that are used in a catalytic converter by most of the manufactures till date are the noble metals. However, the high cost, their sensitivity to sulphur poisoning and limited availability of the precious metals have encouraged researchers to look for alternative catalysts. In the last decade much attention has been paid to the base metals, i.e. due to their higher thermal stability, environmentally friendly properties and lower price, transition metal oxides are suitable alternative for the precious metals. They are less active at low temperatures, but at higher temperatures their activity is similar to that of the noble metals. Many review articles were published keeping in view literature accumulated. Cobalt has been reported and regarded as a good catalyst from economical, thermal stability, activity, selectivity and availability point of view. These properties make it a good catalyst in comparison to other base metal catalysts. Various mechanisms are also proposed in view of $\mathrm{CO}$ oxidation reaction on cobalt based catalysts. These mechanisms are reliable and good enough as per current co-relations present in the literature.

\section{References}

[1] Farrauto R. and Heck R.: Appl. Catal. A, 2001, 221, 443.

[2] Ball D. and Rochester A.: SAE, 1993, 932765.

[3] Brugge D., Durant J. and Rioux C.: Environ. Health, 2007, 6, 23.

[4] Prasad R. and Singh P.: Catal. Rev. Sci. \& Eng., 2012, 54, 224.

[5] Henein N. and Tagomori M.: Progr. Energy \& Combustion Sci., 1999, 25, 563.

[6] Kaspar J., Fornasiero P. and Hickey N.: Catalysis Today, 2003, 77, 419 .

[7] Gallopoulos N.: SAE, 1992, 920721.

[8] Kaiser E., Siegel W., Baidar L. et al.: SAE, 1994, 940963.

[9] Takeda K., Yaegashi T., Sekiquchi K. et al.: SAE, 1995, 950074.

[10] Boam D., Clark T. and Hobbs K.: SAE, 1995, 950930.

[11] Bielaczyc P. and Merkisz J.: SAE, 1997, 970740.

[12] Bhasin M., Nagaki D., Koradia P. et al.: SAE, 1993, 930254.

[13] Summers J., Skowron J. and Miller M.: SAE, 1993, 930386.

[14] Sedjame H.-J., Fontaine C., Lafaye G. and Jr Jacques B.: Appl. Catal. B, 2014, 144, 233.

[15] Janbey A., Clark W., Noordally E. et al.: Chemosphere, 2003, 52, 1041

[16] Papaefthimiou P., Ioannides T. and Verykios X.: Catalysis Today, 1999, 54, 81.

[17] Kintaichi Y., Hamada H., Tabata M. et al.: Catal. Lett., 1990, 6, 239.

[18] Hamanda H.: Catalysis Today, 1994, 22, 21.

[19] Kemball C., Dowden D., Acres G. et al.: Catalysis, 1981, 4, 1.

[20] Bray W., Lamb A. and Frazer J.: J. Ind. Eng. Chem., 1920, 12, 213. 
[21] Wang D.-H., Li M., Shi X.-C. et al.: Purification Techn., 2007, $57,14$.

[22] Taylor S., Hutchings G., Mirzaei A. et al.: Appl. Catal. A, 1998, 166, 143.

[23] Jones C., Cole K., Taylor S. et al.: J. Molec. Catal. A, 2009, $\mathbf{3 0 5}, 121$.

[24] Passos F., Mozer T., Dziuba D. and Vieira C.: J. Power Sources, 2009, 187, 209.

[25] Zeng H., Ji L. and Lin J.: J. Phys. Chem. B, 2000, 104, 1783.

[26] Jansson J.: J. Catalysis, 2000, 194, 55.

[27] Matralis H., Avgouropoulos G., Ioannides T., et. al.: Catalysis Today, 2002, 75, 157.

[28] Cohn G.: US Patent 3216783, Publ. Nov. 09, 1965.

[29] Nieuwenhuys B. and Grisel J.: Catalysis Today, 2001, 64, 69.

[30] Okumura M., Tsubota S. and Haruta M.: J. Mol. Catal. A, 2003, 199, 73.

[31] Olsbye U., Wendelbo R. and Akporiaye D.: Appl. Catal. A, 1997, $152,127$.

[32] Hori G. and Schmidt L.: J. Catalysis, 1975, 38, 335.

[33] Sales B., Tuner J. and Maple M.: Surface Sci., 1981, 112, 272.

[34] Haruta M., Yamada N., Kobayashi T. and Iijima S.: J. Catalysis, 1989, 115, 301.

[35] Igarashi H., Uchida H., Suzuki M. et al.: Appl. Catal. A, 1997, 159, 159.

[36] Ozawa M., Kamiuchi N. and Haneda M.: Catalysis Today, 2013, 201, 79.

[37] Meadowcroft D.: Nature, 1970, 226, 847.

[38] Weidenkaff A.: Adv. Eng. Mat., 2004, 6, 709.

[39] Kaliaguine S., Royer S. and Duprez D.: Catalysis Today, 2006, 112, 99.

[40] Doshi R. and Alcock C.: Catal. Lett., 1993, 18, 337.

[41] Kremenic G., Nieto J., Tascon J. and Tejuca L.: J. Chem. Soc. Faraday Trans., 1985, 81, 939.

[42] Nitadori T., Ichiki T. and Misono M.: Bull. Chem. Soc. Jpn., 1988, 61, 621.

[43] Viswanathan B. and George S.: React. Kinet. Catal. Lett., 1985, 27, 321.

[44] Skoglundh M., Johansson H., Löwendahl L. et al.: Appl. Catal. B, 1996, 7, 299.

[45] Prasad R. and Rattan G.: Bull. Chem. React. Eng. \& Catal., $2010,5,7$.

[46] Backman L., Rautiainen A., Lindblad M. et al.: Appl. Catal. A, 2001, 208, 223.

[47] Rautiainen A., Lindblad M., Backman L. and Puurunen R.: Phys. Chem., 2002, 4, 2466.

[48] Kinoshita T., Seino S., Okitsu K. et al.: J. Alloys \& Comp., 2003, 359, 46.

[49] Zhang J., Sun L. and Liao C.: Solid State Commun., 2002, 124, 45.

[50] Qiaohong Z., Chen C., Min W. et al.: Nanoscale Research Lett., 2011, 6, 586.

[51] Okumura M., Tsubota S. and Haruta M.: J. Mol. Catalysis A, 2003, 199, 73.

[52] Okumura M. and Haruta M.: Chem. Lett., 2000, 29, 396.

[53] Kobayashi T., Haruta M., Tsubota S. et al.: Sensors and Actuators B, 1990, 1, 222.

[54] Zanella R., Giorgio S., Henry C. and Louis C.: J. Phys. Chem. B, 2002, 106, 7634 .

[55] Tömcrona A., Skoglundh M., Thormiihlena P. et al.: Appl. Catal. B, 1997, 14, 131.

[56] Thormählen P., Skoglundh M., Fridell E. and Andersson B.: J. Catalysis, 1999, 188, 300.
[57] Cigdem G. and Filiz B.: Int. J. Hydrogen Energy, 2002, 27, 219.

[58] Kung H. and Kung M.: J. Catalysis, 2003, 216, 425.

[59] Lin H.-K., Wang C.-B., Chiu H.-C. and Chien S.-H.: Catal. Lett., 2003, 86, 63.

[60] Harrison P., Ball I., Daniell W. et al.: Chem. Eng. J., 2003, 95, 47.

[61] Kang M., Song M. and Lee C.: Appl. Catal. A, 2003, 251, 143.

[62] Kang M., Song M. and Kim K.: React. Kinetics \& Catal. Lett., 2003, 79, 3 .

[63] Lin H.-K., Chiu H.-C., Tsai H.-C. et al.: Catal. Lett., 2003, 88, 169.

[64]Grillo F., Natile M. and Glisenti A.: Appl. Catal. B, 2004, 48, 267.

[65] Kwak C., Park T.-J. and Suh D.: Chem. Eng. Sci., 2005, 60, 1211.

[66] Wang C.-B., Tang C.-W., Gau S.-J. and Chien S.-H.: Catal. Lett., 2005, 101, 59.

[67] Pillai U. and Deevi S.: Appl. Catal. B, 2006, 65, 110.

[68] Maier W., Krämer M., Schmidt T. et al.: Appl. Catal. A, 2006, 302, 257.

[69] Wang C.-B., Tang C.-W., Tsai H.-C. et al.: Catal. Lett., 2006, 107, 31 .

[70] Konova P., Stoyanova M. and Stoyanova A.: Appl. Catal. A, 2006, 298, 109.

[71] Yung M., Holmgreen E. and Ozkan U.: Catal. Lett., 2007, 118, 180.

[72] Zhao Z., Yung M. and Ozkan U.: Catal. Commun., 2008, 9, 1465.

[73] Yung M., Zhao Z., Woods M. and Ozkan U.: J. Mol. Catal. A, 2008, 279, 1.

[74] Pollarda M., Weinstocka B., Bitterwolf T. et al.: J. Catalysis, 2008, 254, 218.

[75] Jones C., Taylor S, Burrows A. et al.: Chem. Commun., 2008, 14, 1707.

[76] Luo J., Meng M., Li X. et al.: J. Catalysis, 2008, 254, 310.

[77] Tanga C., Kuo M., Lin C. et al.: Catalysis Today, 2008, 131, 520.

[78] Tseng C., Yang T., Wu H. and Chiang H.: J. Hazardous Mater., 2009, 166, 686.

[79] Njagia E., Chena C.-H., Genuinoa H. et al.: Appl. Catal. B, 2010, 99, 103.

[80] Cole K., Carley A., Crudace M. et al.: Catal. Lett., 2010, 138, 143.

[81] Woods M., Gawade P., Tan B. and Ozkan U.: Appl. Catal. B, 2010, 97, 28.

[82] Njagi E., Genuino H., Kingondu C. et al.: Int. J. Hydrogen Energy, 2011, 36, 6768.

[83] Zhang L., Dong L., Yu W. et al.: J. Colloid Interface Sci., 2011, 355, 464.

[84] Gawade P., Bayram B., Alexander A.-M. and Ozkan U.: Appl. Catal. B, 2012, 128, 21.

[85] Biabani-Ravandi A., Rezaei M. and Fattaha Z.: Chem. Eng. Sci., 2013, 94, 237.

[86] Yan J., Kung M., Sachtler W. and Kung H.: J. Catalysis, 1997, 172, 178.

[87] Horiuchi T., Fujiwara T., Chen L. et al.: Catal. Lett., 2002, 78, 319.

[88] Liotta L., Pantaleo G., Macaluso A. et al.: Appl. Catal. A, 2003, 245, 167.

[89] Sarellas A., Niakolas D., Bourikas K. et al.: J. Colloid Interface Sci., 2006, 295, 165. 
[90] Zhang F., Zhang S., Guan N. et al.: Appl. Catal. B, 2007, 73, 209.

[91] He C., Paulus M., Chu W. et al.: Catalysis Today, 2008, 131, 305.

[92] Hamanda H, Kintaichi Y., Inaba M. et al.: Catalysis Today, 1996, 29, 53.

[93] Ohtsuka H., Tabata T., Okada O. et al.: Catal. Lett., 1997, 44, 265.

[94] Zavyalova U., Scholz P. and Ondruschka B.: Appl. Catal. A, 2007, 323, 226.

[95] Ataloglou T., Vakros J., Bourikas K. et al.: Appl. Catal. B, 2005, 57, 299.

[96] Solsona B., Davies T., Garcia T. et al.: Appl. Catal. B, 2008 , 84, 176.

[97] Sedjame H.-J., Fontaine C., Lafaye G. and Jacques B.: Appl. Catal. B, 2014, 144, 233.

[98] Janbey A., Clark W., Noordally E. et al.: Chemosphere, 2003, 52, 1041.

[99] Papaefthimiou P., Ioannides T. and Verykios X.: Catalysis Today, 1999, 54, 81.

[100] Lauwerys R. and Lison D.: Sci. Total Environ., 1994, 150, 1.

[101] Simonsen L., Harbak H. and Bennekou P.: Sci. Total Environ., 2012, 432, 210.

[102] Stefaniak A., Virji M., Harvey C. et al.: Int. J. Hyg. Environ. Health, 2010, 213, 107.

[103] Karovic O., Tonazzini I., Rebola N. et al.: Biochem. Pharmacology, 2007, 73, 694.

[104] Jager B. and Espinoza R.: Catalysis Today, 1995, 23, 17.

[105] Schulz H.: Appl. Catal. A, 1999, 186, 3.

[106] Apostolia P., Catalania S., Zaghinib A. et al.: Exp. Toxicologic Pathology, 2013, 65, 719.

[107] Persson E., Henriksson J. and Tjälve H.: Toxicology Lett., 2003, 145, 19.

[108] Devaramani S. and Malingappa P.: Electrochimica Acta, 2012, 85, 579.

[109] Zhanga L. and Jahng D.: Waste Management, 2012, 32, 1509.
[110] Kendall N., Mackenzie A. and Telfer S.: Livestock Production Sci., 2001, 68, 31.

[111] Archibald J.: J. Dairy Sci., 1947, 30, 293.

[112] Babel S. and Kurniawan T.: J. Hazardous Mat., 2003, B97, 219.

[113] Che H., Liu A., Fu Q. and Jiang R.: Mat. Lett., 2013, 93, 240

[114] Spătaru T., Anastasescu M., Spătaru N. and Fujishima A.: Electrochem. Commun., 2013, 29, 1.

[115] Yang J., Mu D., Gao Y. et al.: J. Natural Gas Chemistry, 2012, 21, 265.

[116] Habibia D., Farajia A., Arshadib M. et al.: Appl. Catal. A, 2013, 466, 282.

[117] Salek G., Alphonse P., Dufour P. et al.: Appl. Catal. B, 2014, 147,1 .

[118] Suna H., Tian H., Hardjono Y. et al.: Catalysis Today, 2012, 186, 63.

[119] Yao Y.-F.: J. Catalysis, 1974, 33, 108.

[120] Garbowski E., Guenin M., Marion M. and Primet M.: Appl. Catal., 1990, 64, 209.

[121] Cunningham D., Kobayashi T., Kamijo N. and Haruta M.: Catal. Lett., 1994, 25, 257.

\section{ОКИСНЕННЯ МОНОКСИДУ ВУГЛЕЦЮ З ВИКОРИСТАННЯМ КОБАЛЬТОВИХ КАТАЛІЗАТОРІВ: КОРОТКИЙ ОГЛЯД}

Анотація: Розглянуто методи приготування і основні характеристики відомих каталізаторів для окиснення моноксиду вуглецю. В табличній формі приведено короткий огляд літератури основних металовмісних каталізаторів (головним чином, кобальтових) для реакцій окиснення СО.

Ключові слова: кобальт, каталізатор, моноксид вуглецюю, каталітичний конвертор, автомобільні вихлопи. 